\title{
Structural configuration of a large-scale rotational earthslide at Syuchatar, Kathmandu, Nepal
}

\author{
*Naresh Kazi Tamrakar, Suman Manandhar, and Subarna Khanal \\ Central Department of Geology, Tribhuvan University, Kirtipur, Kathmandu, Nepal \\ ("Email: ntamrakar@hotmail.com)
}

\begin{abstract}
After a period of prolonged rain from 9 to 12 September 2005, a large rotational earthslide occurred on 16 September 2005 at Syuchatar in the Kathmandu valley. The horizontal fluvio-lacustrine strata constituting about $47 \mathrm{~m}$ high and $106 \mathrm{~m}$ long cliff as well as about $50 \mathrm{~m}$ wide upper flatland with paddy cultivation slipped towards the Manamati River and dammed it for about 8 hours. Later, its watercourse was restored by excavating a channel through the landslide debris. The earthslide also produced two minor scarps: the upper one with a rotation angle of $38^{\circ}$ and the lower one with a rotation angle of $47^{\circ}$. A stereographic plot of poles to displaced coherent blocks forming the two minor scarps and dispersed fragmented blocks showed that the former had slid towards the northeast $\left(\mathrm{N} 34^{\circ} \mathrm{E}\right.$ and $\left.\mathrm{N} 40^{\circ} \mathrm{E}\right)$, and the latter had dispersed between the azimuths $\mathrm{N} 13^{\circ} \mathrm{W}$ and $\mathrm{N} 60^{\circ} \mathrm{E}$. Though the in-situ infiltration test of the ground gave rather low rates, they were enough to produce a positive porewater pressure for triggering such a type of failure.
\end{abstract}

\section{INTRODUCTION}

Rapid urbanisation during the last decade in the Kathmandu valley has resulted in a haphazard growth of buildings and infrastructures. It is also responsible for significant changes in the landscape as well as encroachment of the floodplain and riverbed. Such anthropogenic activities have not only polluted the natural environment but also accelerated streambank erosion and mass movements (Tamrakar 2004). The landslide of Syuchatar (Fig. 1) is one of such examples.

A large rotational earthslide occurred about $2.5 \mathrm{~km} \mathrm{NW}$ of Kalanki in the Manamati River valley (in the Syuchatar VDC, near Durga Nagar Colony) at the midnight of 16 September 2005 after a period of continuous rainfall from 9 to 12 September 2005. During the landslide event, the horizontal fluvio-lacustrine strata constituting about $47 \mathrm{~m}$ high and $106 \mathrm{~m}$ long cliff as well as about $50 \mathrm{~m}$ wide upper flatland with paddy cultivation slipped towards the Manamati River. The earthslide dammed the river for about 8 hours. Later, its watercourse was restored by excavating a channel through the landslide debris. Though no human casualty was recorded, a large portion of fertile land with paddy was destroyed. The landslide also endangered a few houses located near its crown.

The Manamati watershed is located in the southwest of Kathmandu. It is a forth-order stream of the Bishnumati River (Fig. 1). The watershed is surrounded from the north, west, and south by the topographic heights with elevations of
2000, 1500, and $1700 \mathrm{~m}$, respectively. These divides are composed of metasedimentary rocks belonging to the Phulchauwki Group (Stöcklin and Bhattarai 1977; DMG 1998).

The watershed is elongated in the NW-SE direction and contains gently dipping terraces composed of fluviolacustrine sediments of the Lukundol Formation (Yoshida and Igarashi 1984) comprising thick black clay, gravel, sand, and silt beds. The relative relief of these terraces varies from 10 (upstream) to $60 \mathrm{~m}$ (downstream).

The Manamati River is incised into the terrace deposits. The incision is prominent in the areas upstream from the landslide. The crown of the landslide is $47 \mathrm{~m}$ high. In the landslide region, the river is slightly entrenched with a relatively high flow capable of scouring its riverbanks. It is a perennial river that can carry cobbles and pebbles during a high flow.

\section{TOPOGRAPHY OF LANDSLIDE AREA}

A detailed (1:500) topographic survey of the landslide area was carried out on 1 October 2005 to reveal its morphology. At the same time, detailed field investigations were also done to assess its failure mechanism.

The hillslope in the vicinity of the landslide was classified following Young (1964). The natural slope on the left flank of the landslide has an upper steep slope $\left(29^{\circ}\right)$ and a lower moderately steep slope $\left(13^{\circ}\right)$. The slope angle decreases gradually from the middle to the lower part (Fig. 2). The 


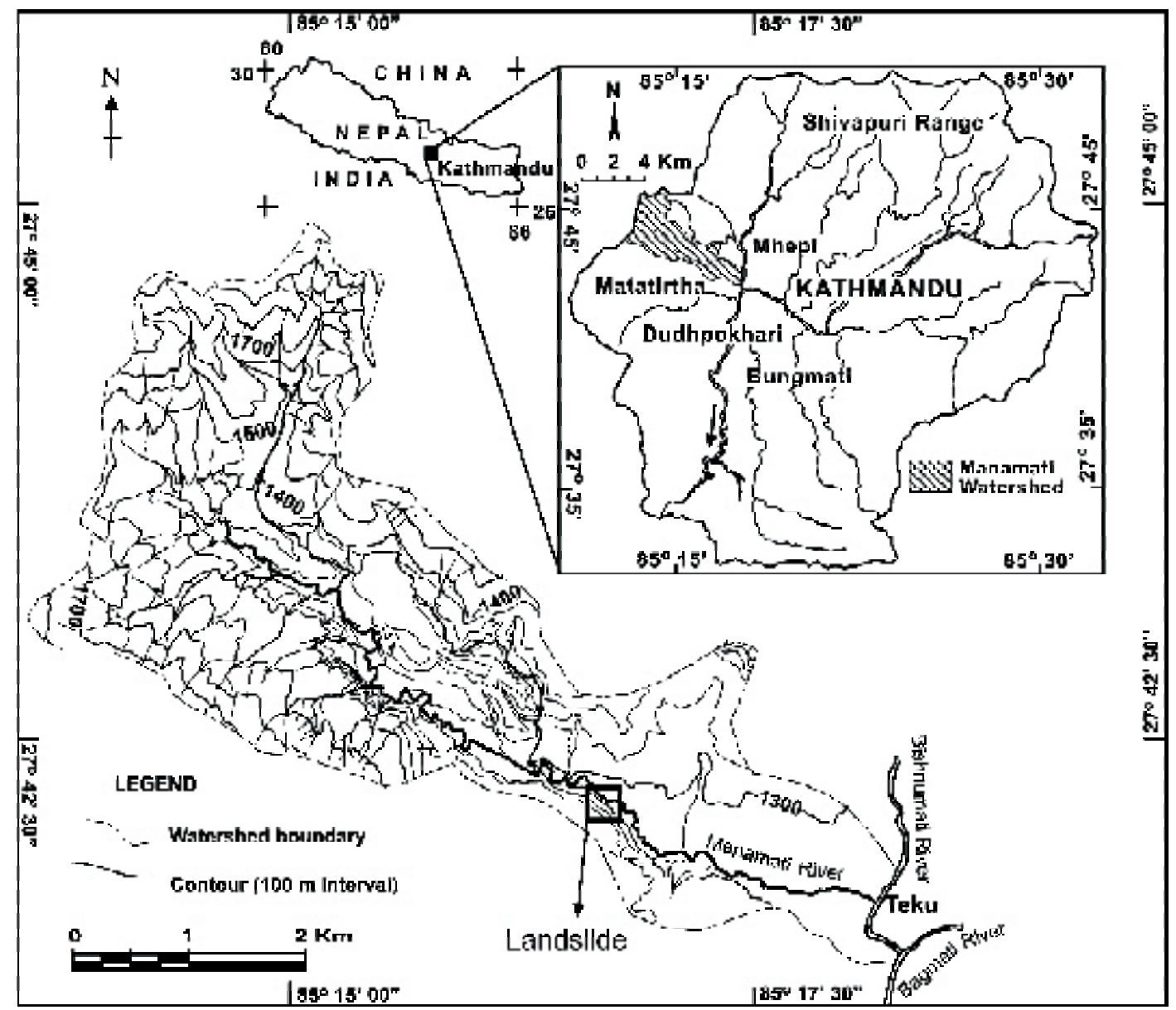

Fig. 1:Topography and drainage system of the Manamati watershed showing location of the landslide

natural slope on the right flank has an upper very steep slope $\left(37^{\circ}\right)$, a middle moderately steep slope $\left(10^{\circ}-18^{\circ}\right)$, and a lower moderate slope $\left(10^{\circ}\right)$. The middle and lower slopes are the artificially modified surfaces.

The crown is almost a level surface (Fig. 2). Cracks are well developed in the vicinity of the crown. The main scarp has a very steep slope $\left(43^{\circ}\right)$, while the head has a steep slope $\left(21^{\circ}\right)$. Two minor scarps are found close to each other and are prominent towards the left flank. They also exhibit a very steep slope of about $35^{\circ}$. On the right flank of the landslide, the slope is moderately steep and forms a spur. On the left flank of the landslide, a minor scarp has a steep slope of about $26^{\circ}$. Some small-scale slump scars are located between the main and minor scarps. A transverse depression exists north of the minor scarp, whereas a radial depression occurs to the northwest of the spur on the right flank. Numerous narrow depressions also exist at the head and the zone of depletion adjacent to the minor scarp (Fig. 2). Between this depression and the foot of the landslide, there are respectively very gentle and moderate $\left(13^{\circ}\right)$ concave slopes exhibiting a slight bulge. But, locally there exist many irregularities due to the presence of blocks of debris. Further down, the foot of the slope has a narrow mound-like feature parallel to the river, produced during the excavation of a channel through the landslide dam. The landslide toe is very gentle and is located on the left bank of the Manamati River.

After the first survey, the landslide was monitored to obtain information on its activity.

The area between the minor scarp and foot as well as from the middle to lower slope on the right flank are being modified due to slow mass movements and anthropogenic activities. A large quantity of spoil is accumulated on the right flank. Two minor scarps are still clearly visible on the left flank of the landslide, but they are buried towards the right flank by the spoil.

\section{Lithology}

The original slope before failure was composed of stratified yellowish grey, light grey to dark grey mud with plant fossils and pebbly sand (Fig. 4). Most of the main scarp is made up of mud beds (Fig. 5a), which are coherent. Some pebbly sand beds of 0.2 to $1.5 \mathrm{~m}$ thickness are intercalated with mud beds at depths between 8 and $12 \mathrm{~m}$ (Fig. 4). 


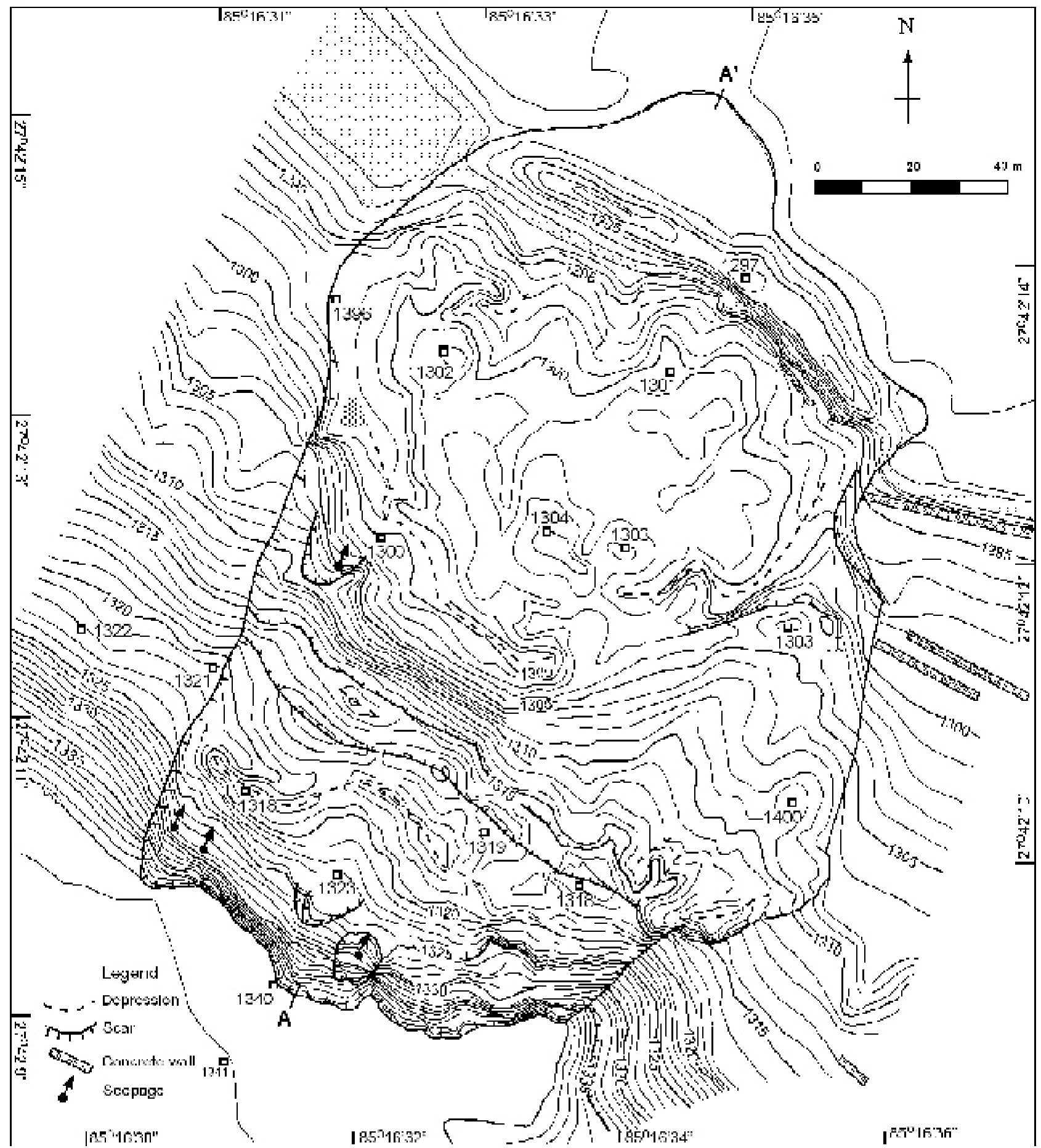

Fig. 2: Topographic map of the first surveyed landslide area in 2005

In the landslide area, the main scarp and flanks exhibit the original stratified deposits (Fig. 3). The minor scarps (Figs. 3, 5b) exhibit somewhat coherent strata dipping southwards or towards the uphill direction. Utterly fragmented blocks of the cohesive strata containing the relicts of stratification are dispersed in the area between the minor scarp and the foot (Fig. 5c). Smaller cohesive blocks of clay and silt are dispersed further down, up to the tip of the landslide. The foot contains a jumble of landslide debris, river channel sediments, plant debris, and pieces of concrete wall.

Seepage is extensive in the vicinity of main and minor scarps (Figs. 2, 3). Seepage is also observed on the natural slopes also. Owing to the land modification and construction 


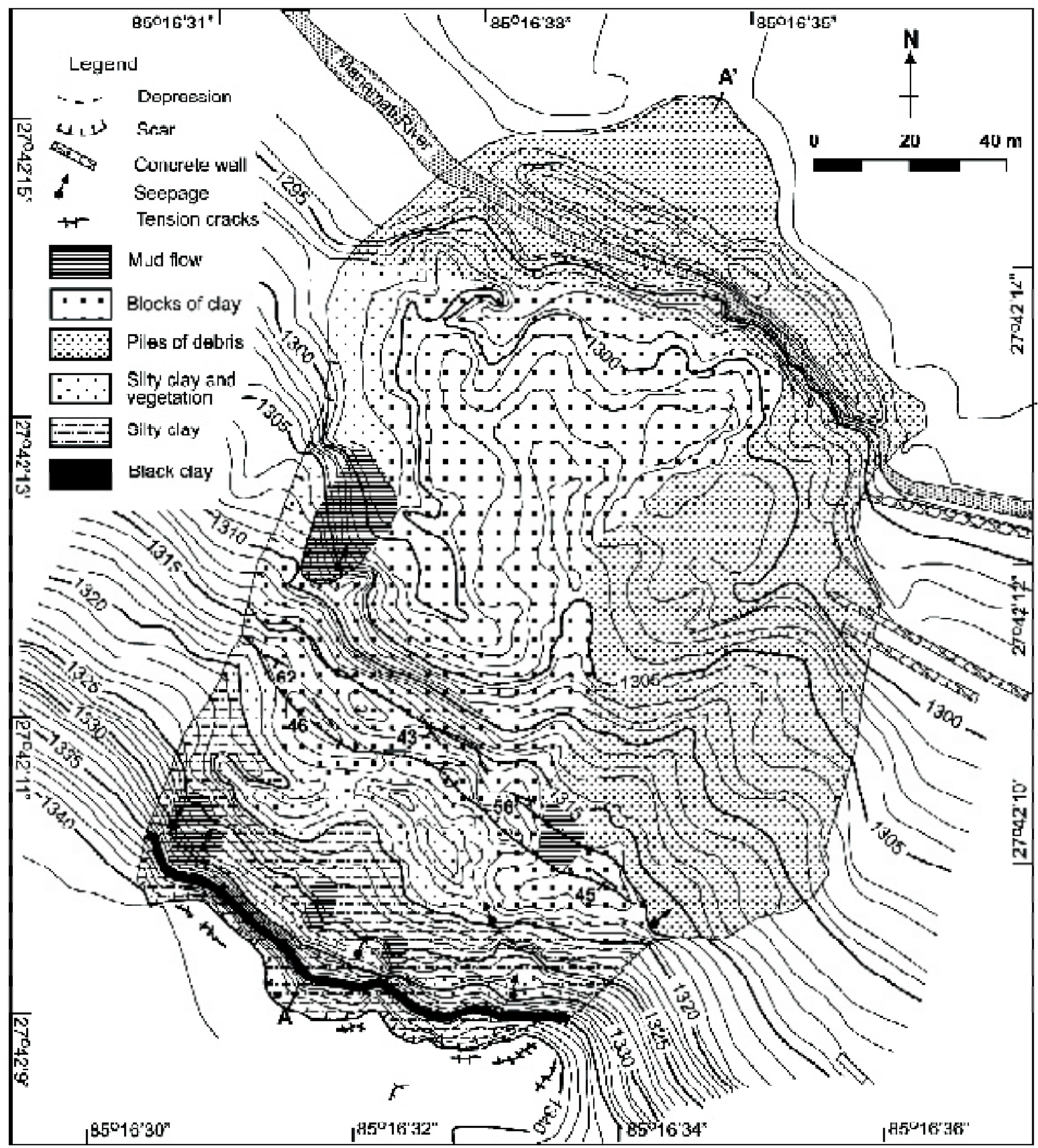

Fig. 3: Geological map of landslide area monitored in 2006

of concrete walls (Fig. 5d), subsurface as well as overland flows were checked and directed towards the foot of the slope and could have triggered the slide.

\section{Landslide geometry}

Following Cruden and Varnes (1996), a longitudinal profile (Fig. 6) and a topographic map (Fig. 2) of the landslide area were used to obtain its dimensional parameters (Table 1). The zone of depletion extends for about $45 \mathrm{~m}$. The zone of accumulation of the main body is about $85 \mathrm{~m}$ long. The span between inferred slip surface and toe is about $70 \mathrm{~m}$. A graphical reconstruction of the minor scarps to their original slope configuration allowed the estimation of a depth of slip surface at $27 \mathrm{~m}$. The volume of depleted mass (volume of displaced material that overlies the surface of rupture but underlies the original ground surface) was $21.00 \times 10^{4} \mathrm{~m}^{3}$. The volume of displaced material (material displaced from its original position on slope and constituting both depleted 


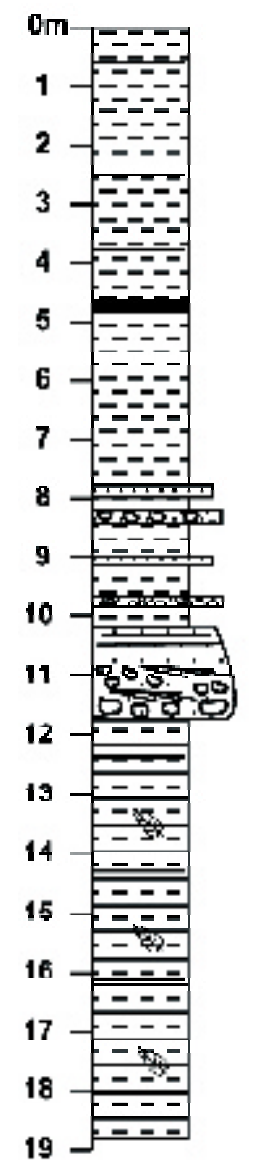

light grey muxl

ycllowish grey mud

interralatinn of hrrumish grey and light grey mud

black carbonaceous mud

yellowish grey and light grey mud

gravelly sand

gravelly sand with cross-beds in the lower part. fines up ward nto laminated sand

Intercalation of black and brown mud

Iaminated dark grey mud with plant fossil, and intertedded with several laypers of silt

Fig. 4: Litholog of the original strata in the vicinity of landslide

and accumulated masses) was $26.48 \times 10^{4} \mathrm{~m}^{3}$. The displaced material could have been dilated and then partly removed by erosion. The length and height of the landslide were $203 \mathrm{~m}$ and $47 \mathrm{~m}$, respectively. In 2006, a small slope failure occurred on the main scarp, and the length of landslide changed from $203 \mathrm{~m}$ to $219 \mathrm{~m}$.

\section{CAUSES AND MECHANISMS OF FAILURE}

The hillslopes of the Manamati watershed are subject to valley rebound due to the river incision. Toe erosion of the hillslope and removal of lateral support contributed to the instability.

Prior to the landslide event, there was a precipitation of $29.3 \mathrm{~mm}$ on 9 September 2005 (DHM 2005). Then, a prolonged rainfall (up to 12 September) had contributed to a cumulative precipitation of $50.7 \mathrm{~mm}$. The rainwater infiltrated into and percolated through the strata to reach the shallow water table lying at a depth of $12 \mathrm{~m}$. Consequently, the resulting porewater pressure triggered the failure.

A double-ring infiltrometer was used to determine the permeability of soils in the crown. Though the measured
Table 1: Dimensional parameters of the Syuchatar Landslide

\begin{tabular}{l|r}
\hline \multicolumn{1}{c|}{$*$ Geometric parameters of landslide } & \multicolumn{1}{c}{ value } \\
\hline Length of surface of rupture, $\mathrm{L}_{\mathrm{r}}(\mathrm{m})$ & 127.78 \\
\hline Depth of surface of rupture, $\mathrm{D}_{\mathrm{r}}(\mathrm{m})$ & 27.05 \\
\hline Width of surface of rupture, $\mathrm{W}_{\mathrm{r}}(\mathrm{m})$ & 116.00 \\
\hline Volume of depleted mass, $\mathrm{V}_{\mathrm{r}}=\left(? \mathrm{~L}_{\mathrm{r}} \cdot \mathrm{W}_{\mathrm{r}} \cdot \mathrm{D}_{\mathrm{r}}\right) / 6\left(\mathrm{~m}^{3}\right)$ & $21.00 \times 10^{4}$ \\
\hline Length of displaced mass, $\mathrm{L}_{\mathrm{d}}(\mathrm{m})$ & 149.91 \\
\hline Depth of displaced mass, $\mathrm{D}_{\mathrm{d}}(\mathrm{m})$ & 29.08 \\
\hline Width of displaced mass, $\mathrm{W}_{\mathrm{d}}(\mathrm{m})$ & 116.00 \\
\hline Volume of displaced material, $\mathrm{V}_{\mathrm{d}}=\left(\right.$ ? $\left.\mathrm{L}_{\mathrm{d} .} \cdot \mathrm{W}_{\mathrm{d}} \cdot \mathrm{D}_{\mathrm{d}}\right) / 6\left(\mathrm{~m}^{3}\right)$ & $26.48 \times 10^{4}$ \\
\hline Total length, $\mathrm{L}(\mathrm{m})$ & 202.68 \\
\hline Total height, $\mathrm{H}(\mathrm{m})$ & 46.45 \\
\hline
\end{tabular}

*Definition of parameters is after Cruden and Varnes (1996)

infiltration rate (Fig. 7) was quite slow (i.e. $0.53 \times 10^{-2} \mathrm{~m} / \mathrm{hr}$ ), it was responsible to produce a positive porewater pressure.

A housing company had reclaimed the slope by constructing a masonry wall on the right bank of the river, which presumably hindered the drainage system and adversely affected the north-facing slopes in September 2005. Consequently, the overland flow infiltrated into and percolated through the ground was obstructed by the concrete masonry wall, and had ultimately concentrated towards the foot of the slope. It increased the porewater pressures leading to sliding.

The huge rotational earthslide appeared with two minor scarps and several fragmented blocks. The slip surface of the first minor scarp extended from the crown to the foot of the earthslide. The second minor scarp was produced due to successive slumping in the body of the first slumped mass. The dip directions and amounts of the first and second minor scarps were $34^{\circ} / 35^{\circ}$ and $40^{\circ} / 26^{\circ}$, respectively.

The scattered plots of fragmented blocks (Fig. 8a) signify a burst phenomenon. The poles to the strata constituting the minor scarps and fragmented blocks (up to $2 \mathrm{~m}$ in length) show that the major direction of dispersal of blocks varied between $\mathrm{N} 13^{\circ} \mathrm{W}$ and $\mathrm{N} 60^{\circ} \mathrm{E}$ (Fig. $8 \mathrm{~b}$ ). Two directional trends of rotation of blocks forming the first and second minor scarps were $34^{\circ}$ and $40^{\circ}$, respectively. Similarly, the rotation angles of the beds constituting the two minor scarps were respectively $38^{\circ}$ and $47^{\circ}$.

\section{Present status of earthslide}

After the main event of 2005, a number of small slope failures were observed around its main scarp in the monsoon season, indicating a retrogressive tendency of the earthslide. A recent monitoring has revealed a number of shallow mudflows from the landslide head and scarps (Fig. 9). Furthermore, the housing company has continued landscaping the slopes on the right flank of the earthslide and it has piled up the spoil without considering the slope stability. Since there are numerous cracks in the crown (Fig. 9) and a portion of it still continues to slide, the landslide may reactivate in the future. 

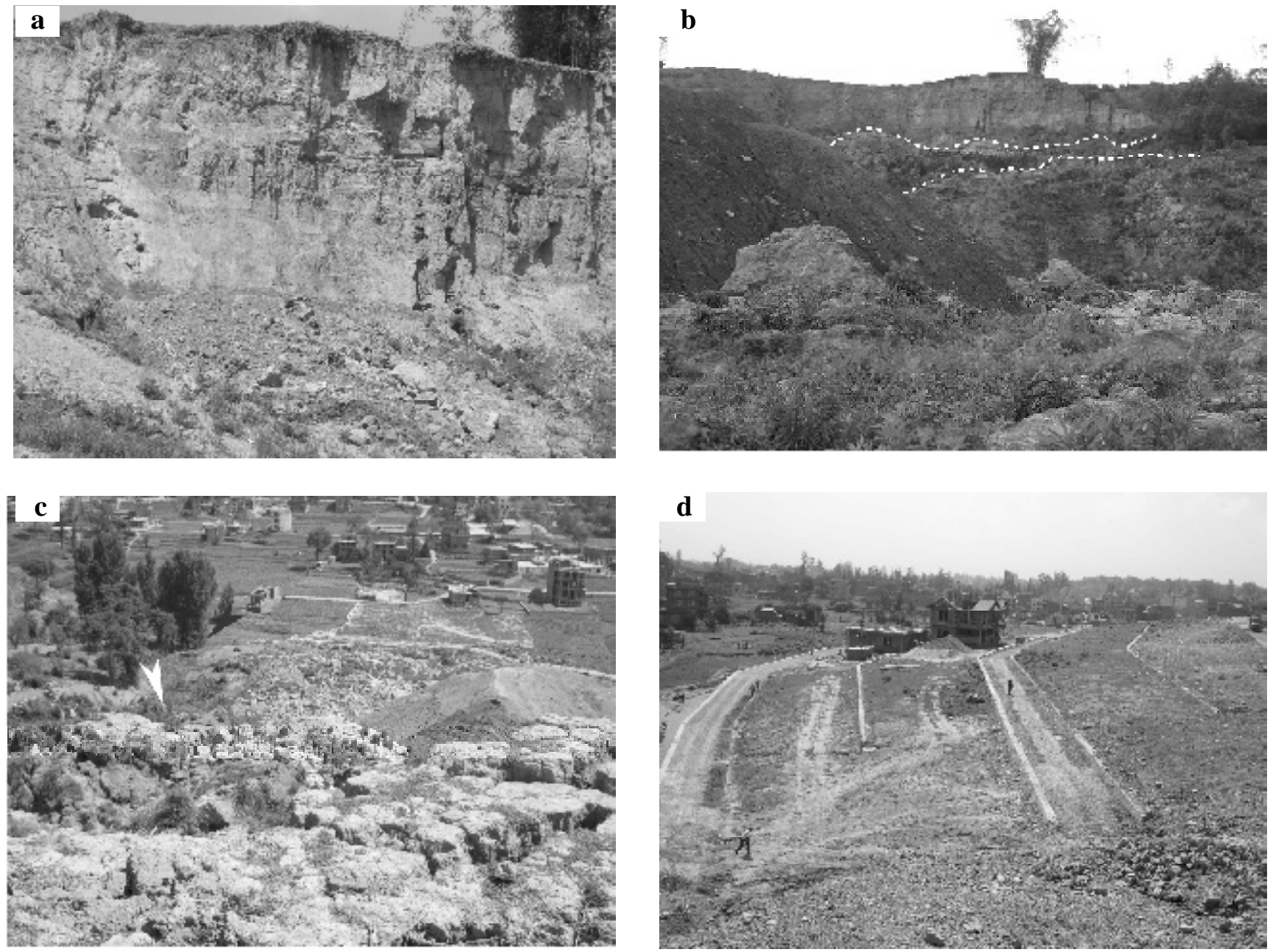

Fig. 5: Photographs showing: (a) Main scarp and strata; (b) Two minor scarps (dashed lines); (c) View of landslide from its crown depicting the decreasing size of debris down the slope (white and black arrows represent a small pond formed after sliding); (d) A close eastern view from the right flank showing three motorable lanes and concrete walls across the slope (note the modification of slope and narrowing down of riverbank)

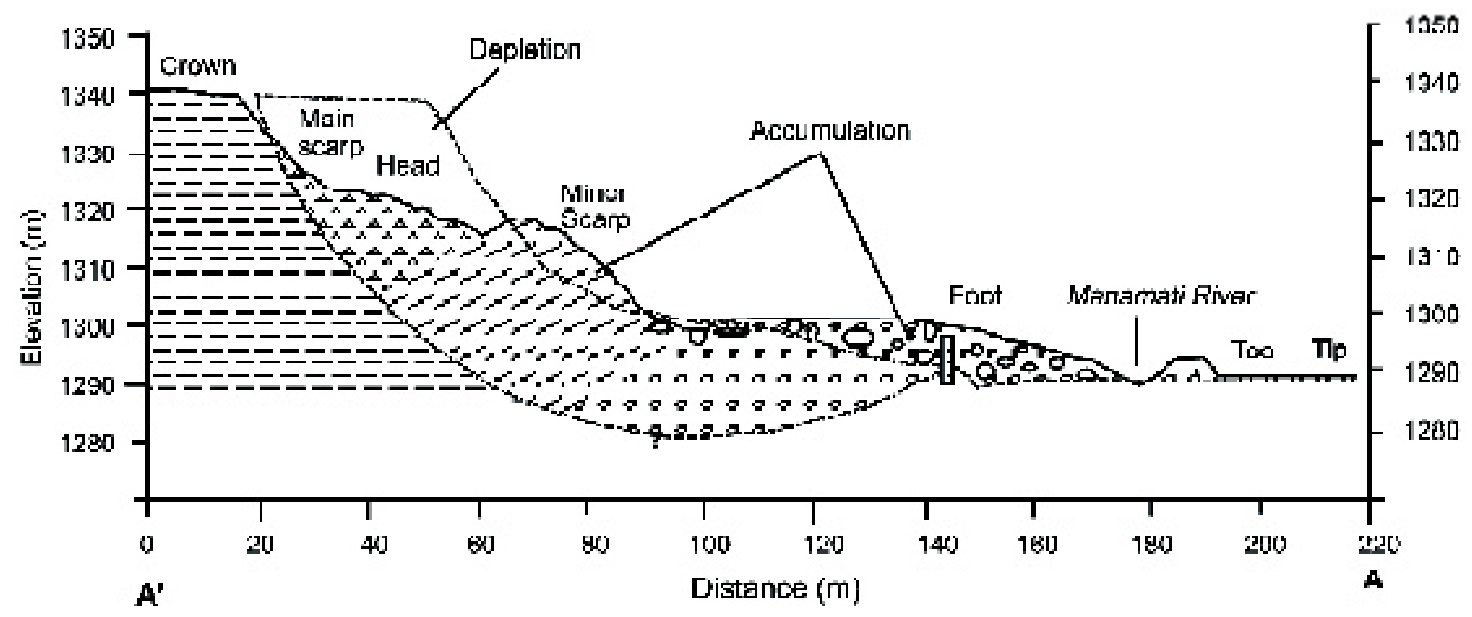

Fig. 6: Profile along A-A' showing the landslide topography and its various elements 


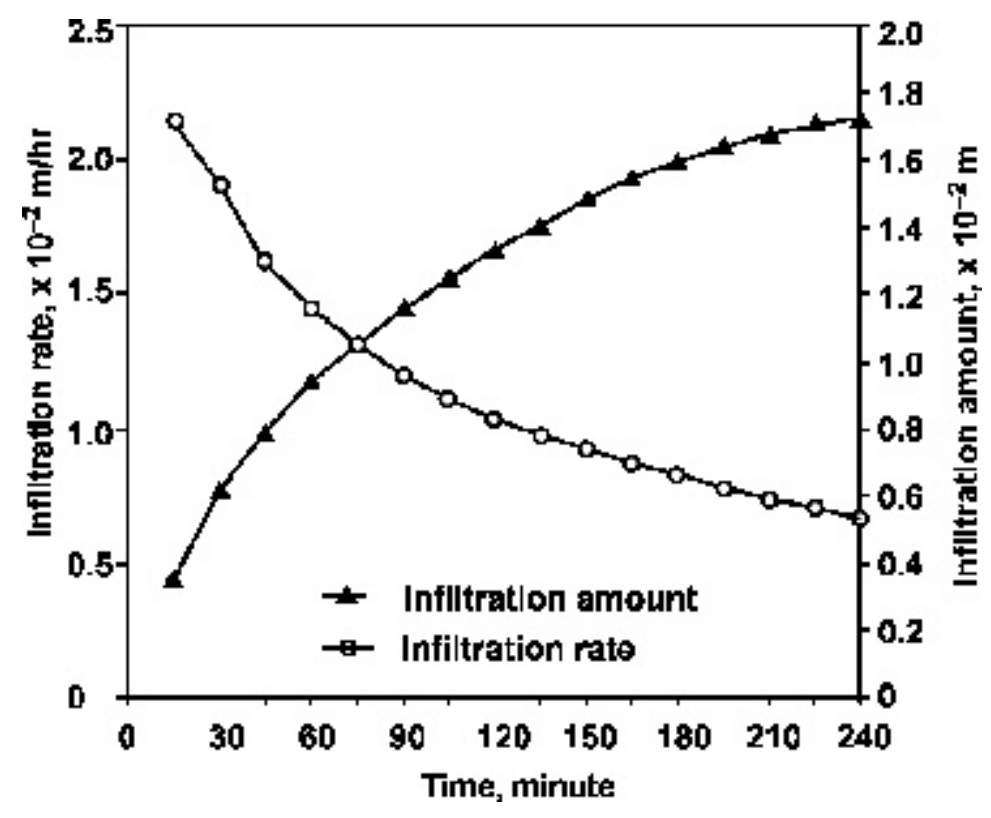

Fig. 7: Plot of infiltration rate and amount against time (data from double-ring infiltration test)
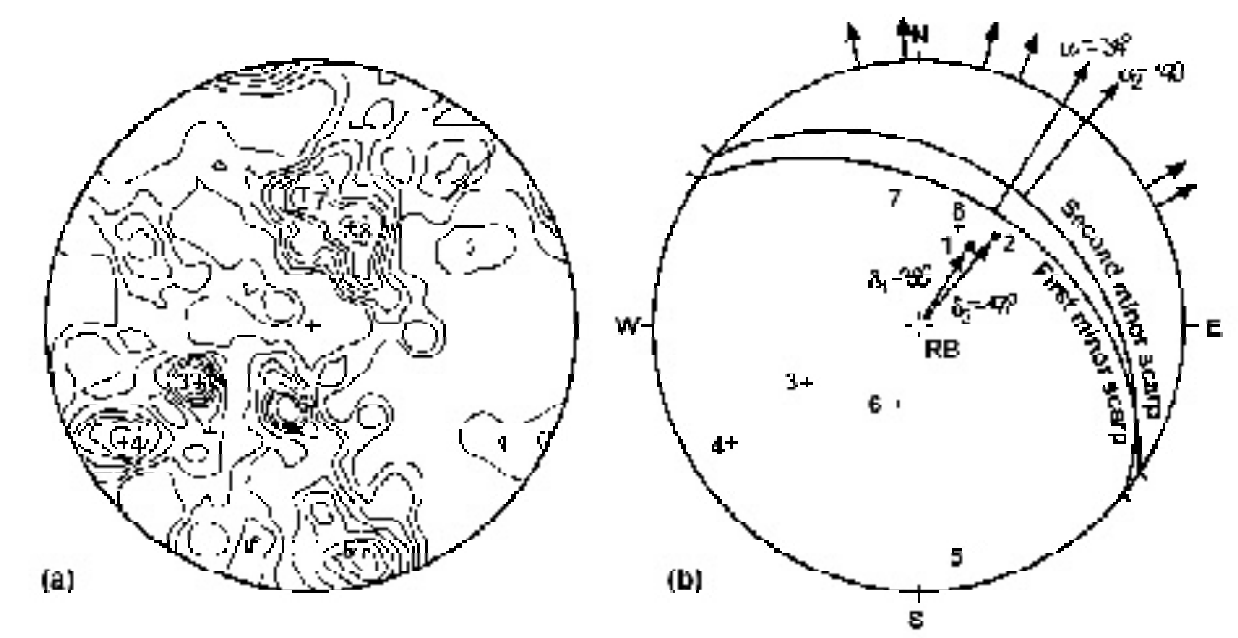

\section{LEGEND}

$+3,4,5,6$ Palea of elspersad blacks; laminas dip northoast

\section{$+T, 8$ Poloe of dieporead blocks;}

bamInas dlp sauth

- 1 Pole of hod 1 in first minor scam

- 2 Pole or bed $\mathbf{z}$ irl gecorid mirns ycarp
C RB Regional bed

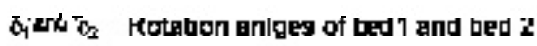

$\sigma_{1}$ and $\mathrm{rs}$, Azimuthe of robat|on of mingr scarp 1 and bed 1. and ininor scarp 2 and bed 2 , respectively

Kinomatice of cliepereal of blacke from lantalide shawing disparsal direction

Fig. 8(a): Stereographic projection of attitudes (poles) showing direction of landsliding and pattern of dispersal of debris in landslide area (b) Kinematic analyses of blocks. 


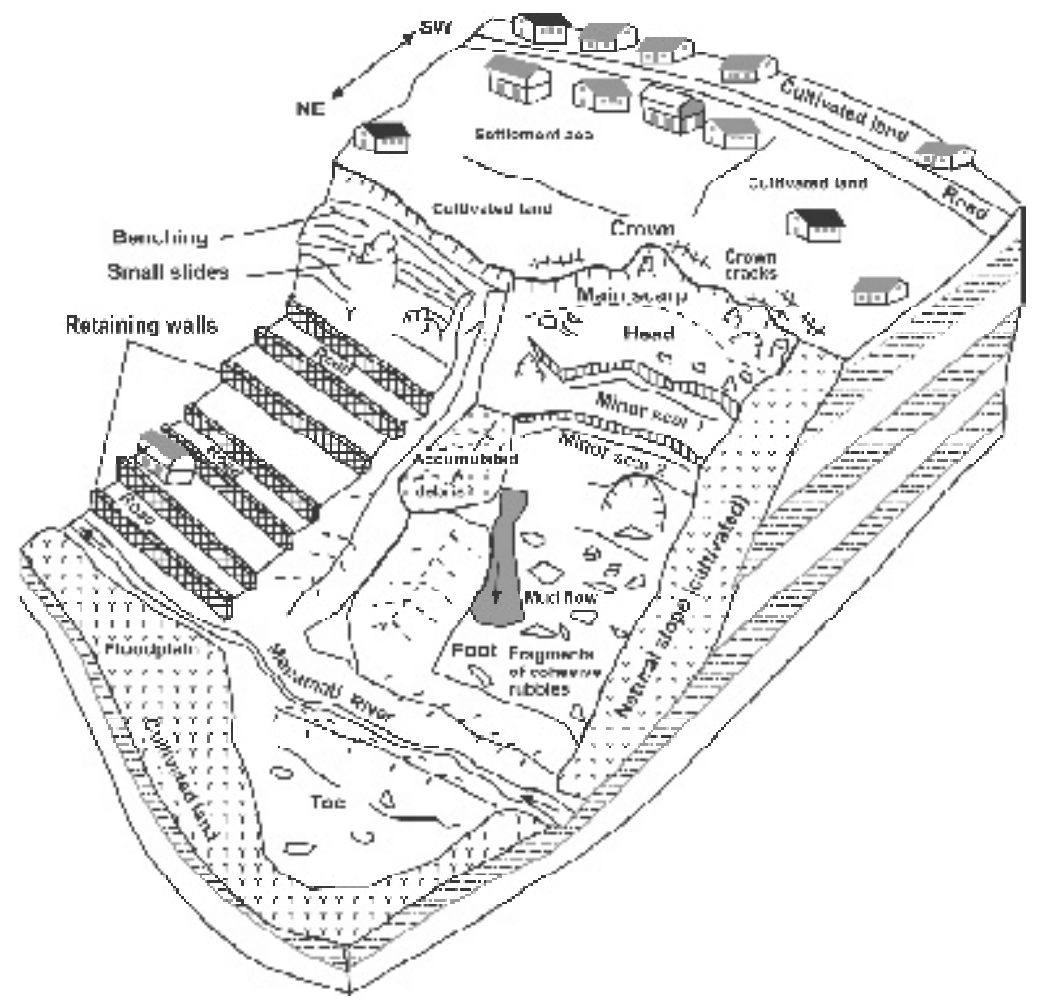

Fig. 9: Three-dimensional view of the rotational earthslide in 2007

\section{CONCLUSIONS}

The volume of the depleted mass and that of the displaced material after the landsliding were $21.00 \times 10^{4}$ and $26.48 \times 10^{4}$ $\mathrm{m}^{3}$, respectively. The landslide is a large-scale rotational earthslide that experienced successive sliding and gave rise to two minor scarps.

Valley rebound and anthropogenic disturbances of slope were the major causes, and rainfall was the trigger of the rotational earthslide. The in-situ filtration rate at the flattopped crown was $0.53 \times 10^{-2} \mathrm{~m} / \mathrm{hr}$ of low infiltration rate that was responsible to produce positive pore water pressure laterally.

The trend and plunge of two main scarps were respectively $34^{\circ} / 35^{\circ}$ and $40^{\circ} / 26^{\circ}$ with the difference of both direction of rotation and degree of rotation. The stereographic projection of poles to the original strata and the dispersed huge blocks forming minor scarps showed that the blocks slid towards $\mathrm{N} 34^{\circ} \mathrm{E}$ and $\mathrm{N} 40^{\circ} \mathrm{E}$, and rotated respectively to $38^{\circ}$ and $47^{\circ}$. The fragmented blocks had dispersed between $\mathrm{N} 13^{\circ} \mathrm{W}$ and $\mathrm{N} 60^{\circ} \mathrm{E}$.

\section{ACKNOWLEDGEMENTS}

Authors are thankful to Mr. C. B. Shrestha and Mr. S. Maharjan for assistance during field survey. Authors thank A. M. S. Pradhan for assisting in the landslide monitoring.

\section{REFERENCES}

Cruden, D. M. and Varnes, D. J., 1996, Landslide types and processes. In: Special Report 247: Landslides: investigation and mitigation (A. Keith Turner, Robert L Schuster, eds.), TRB, National Research Council, Washington, D.C., pp. 36-99.

DHM, 2005, Rainfall data recorded in the Thankot Station, Kathmandu. Digital data in CD-Rom, Department of Hydrology and Meteorology (DHM), Government of Nepal, Babar Mahal, Kathmandu, Nepal.

DMG, 1998, Engineering and environmental geological map of the Kathmandu Valley, scale 1:50,000. Department of Mines and Geology (DMG), Lainchaur, Kathmandu, Nepal.

Stöcklin, J. and Bhattarai, K. D., 1977, Geology of the Kathmandu area and Central Mahabharat range, Nepal Himalaya. Report of Department of Mines and Geology/ UNDP (unpublished report), 86p.

Tamrakar, N. K., 2004, Disturbances and instabilities in the Bishnumati River corridor, Kathmandu basin, JUSAN, v. 9(16), pp. 7-18.

Yoshida, M. and Igarashi, Y., 1984, Neogene to quaternary lacustrine sediments in the Kathmandu Valley, Nepal, Jour. Nepal Geol. Soc., Sp. Issue, v. 4, pp. 73-100.

Young, A., 1964, Slope profile analysis, Slopes Comm. Rep., v. 4, pp.17-27. 


\title{
Instructions to Contributors
}

\section{Manuscript}

Send a disk file (preferably in MS Word) and three paper copies of the manuscript, printed on one side of the paper, all copy (including references, figure captions, and tables) double-spaced and in 12-point type with a minimum $2.5 \mathrm{~cm}$ margin on all four sides (for reviewer and editor marking and comment). Include three neat, legible copies of all figures. Single-spaced manuscripts or those with inadequate margins or unreadable text, illustrations, or tables will be returned to the author unreviewed.

The acceptance or rejection of a manuscript is based on appraisal of the paper by two or more reviewers designated by the Editorial Board. Critical review determines the suitability of the paper, originality, and the adequacy and conciseness of the presentation. The manuscripts are returned to the author with suggestions for revision, condensation, or final polish.

After the manuscript has been accepted, the editors will ask the author to submit it in an electronic format for final processing. Manuscripts are copy edited. Final changes must be made at this time, because no galley proofs are sent to authors.

\section{Illustrations}

Identify each figure (line drawing, computer graphic, or photograph) with the author's name, and number consecutively, at the bottom, outside the image area. Never use paper clips or tape on illustrations and do not write with pen on the back of figure originals or glossy prints. Where necessary, mark "top". Keep the illustrations separate from the text, and include a double-spaced list of captions. Do not put captions on the figures themselves.

Prepare clean, clear, reproducible illustrations that are drafted at a size not more than twice the publication size. All lettering on illustrations must be drafted or laser printed, not typed or handwritten. Put type, labels, or scales directly on a photograph rather than on a separate overlay. Use graphic scales on illustrations; verbal scales (e.g., "x200”) can be made meaningless by reduction of an illustration for printing. Calibrate graphic scales in metric units. Indicate latitude and longitude on maps. Plan all type sizes large enough so that the smallest letters will be at least $1.5 \mathrm{~mm}$ tall after reduction to publication size. For review purposes, copies of illustrations must be legible and relatively easy to handle, and any photographs must be direct prints. Do not send original illustrations until asked to do so. Keep at least one copy of all illustrations, as the NGS cannot be responsible for material lost in the mail.

For colour figures, authors must bear all costs, and about $\$ 50$ per colour figure/plate will be charged.

\section{Style}

Authors are responsible for providing manuscripts in which approved geological and other scientific terminology is used correctly and which have no grammar or spelling errors. Authors must check their manuscripts for accuracy and consistency in use of capitalisation, spelling, abbreviations, and dates.

\begin{abstract}
The abstract should present information and results in capsule form and should be brief and objective, containing within a 250-word maximum the content and conclusions of the paper. The topic sentence should give the overall scope and should be followed by emphasis on new information. Omit references, criticisms, drawings, and diagrams.
\end{abstract}

\section{Captions}

Make captions precise and explain all symbols and abbreviations used. Type captions in consecutive order, doublespaced. Do not put captions and figures on the same page.

\section{References}

All references mentioned in the text, figures, captions, and tables must be listed in the References section. Only references cited in the paper are to be listed. For example:

Auden, J. B., 1934, Traverses in the Himalaya. Rec. Geol. Surv. India, v. 69(2), pp. 133-167.

Todd, D. K., 1980, Groundwater Hydrology. John Wiley \& Sons, Singapore, 535 p.

Tokuoka, T. and Yoshida, M., 1984, Some characteristics of Siwalik (Churia) Group in Chitwan Dun, Central Nepal. Jour. Nepal Geol. Soc., v. 4, (Sp. Issue), pp. 26-55.

\section{Reprints}

Authors will receive twenty-five copies of reprints free of cost. Additional copies may be ordered for purchase when proofs are returned to the editor.

\section{Submission of Manuscripts}

The manuscripts and all the correspondences regarding the Journal of Nepal Geological Society should be addressed to the Chief Editor, Nepal Geological Society, PO Box 231, Kathmandu, Nepal (Email: publication@ngs.org.np). 